JKT, 2019;10(1):30-35. Hubungan antara Pengetahuan, Motivasi, dan Dukungan. Sari Hanum, Nona Rahmaida Puetri, Marlinda, Yasir

\title{
HUBUNGAN ANTARA PENGETAHUAN, MOTIVASI, DAN DUKUNGAN KELUARGA DENGAN KEPATUHAN MINUM OBAT PADA PENDERITA HIPERTENSI DI PUSKESMAS PEUKAN BADA KABUPATEN ACEH BESAR \\ Correlation between Knowledge, Motivation and Family Support with The Compliance of Drug in Hypertension Patients in Puskesmas Peukan Bada Aceh Besar District
}

\author{
Sari Hanum ${ }^{1}$, Nona Rahmaida Puetri ${ }^{1}$, Marlinda ${ }^{1}$, Yasir $^{1}$ \\ ${ }^{1}$ Loka Penelitian dan Pengembangan Biomedis Aceh, Jalan Bandar Iskandar Muda, Lorong: \\ Tgk. Dilangga No. 9, Lambaro Aceh Besar \\ Email: sarihanum82@gmail.com
}

\begin{abstract}
Hypertension is a disease that is known as the silent killer disease or quietly because in general people do not know he suffered from hypertension before they check their blood pressure. The purpose of this study was to look at factors related to adherence to taking anti-hypertension medication. Using descriptive analytic design through Cross Sectional approach. The data were collected by interview using questionnaire. Population in this research in Peukan Bada Public Health Center are 56 people. This study used Chi-Square statistic test. The result of the research showed that hypertension patient mostly good $(55,4 \%)$, hypertension motivation mostly high $(64,3 \%)$ and hypertension family support mostly good $(60,7 \%)$. The result of the statistical test shows that there is correlation between knowledge ( $p$ value $=0,001)$, motivation ( $p$ value $=0,002$ ) with adherence to taking anti hypertension medication in hypertension patient and no relation with family support ( $\mathrm{p}$ value $=0,728$ ) with adherence to taking anti hypertensive drugs in hypertensive patients.
\end{abstract}

Keywords: Hypertension, knowledge, motivation, patient family support

\begin{abstract}
ABSTRAK
Hipertensi merupakan salah satu penyakit yang dikenal dengan sebutan the silent disease atau pembunuh diam-diam karena pada umumnya penderita tidak mengetahui dirinya mengidap hipertensi sebelum memeriksa tekanan darahnya. Tujuan penelitian untuk menentukan faktor yang berhubungan dengan kepatuhan minum obat anti hipertensi. Analisis data desain deskriptif analitik melalui pendekatan cross sectional. Pengumpulan data dilakukan dengan wawancara menggunakan kuesioner. Populasi dalam penelitian ini penderita hipertensi di wilayah kerja Puskesmas Peukan Badasebanyak 56 orang. Penelitian ini menggunakan Chi-Square Test.Hasil penelitian diperoleh pengetahuan penderita hipertensi sebagian besar baik $(55,4 \%)$, motivasi penderita hipertensi sebagian besar tinggi $(64,3 \%)$ dan dukungan keluarga penderita hipertensi sebagian besar baik $(60,7 \%)$ dan tingkat kepatuhan minum obat penderita hipertensi memiliki persentase yang sama antara patuh dan tidak patuh $(50 \%)$. Hasil uji statistik diperoleh ada hubungan antara pengetahuan ( $p$ value $=0,001)$, motivasi $(p$ value $=0,002)$ dengan kepatuhan minum obat anti hipertensi. Tidak ada hubungan dengan dukungan keluarga $(p$ value $=0,728)$ terhadap kepatuhan minum obat anti hipertensi.
\end{abstract}

Kata kunci: Dukungan keluarga pasien, hipertensi, motivasi, pengetahuan 
JKT, 2019;10(1):30-35. Hubungan antara Pengetahuan, Motivasi, dan Dukungan.

Sari Hanum, Nona Rahmaida Puetri, Marlinda, Yasir

\section{PENDAHULUAN}

Hipertensi atau tekanan darah tinggi merupakan salah satu faktor risiko penyakit kardiovaskuler dengan prevalensi dan kematian yang cukup tinggi terutama di negaranegara maju dan daerah negara berkembang termasuk Indonesia. Hipertensi disebabkan oleh adanya tekanan darah tinggi yang melebihi normal ${ }^{1}$.Saat ini hipertensi masih menjadi masalah kesehatan utama. Berdasarkan data World Health Organization (WHO) 2013 diperkirakan 1 dari 3 orang dewasa atau sekitar 1 milliar orang didunia menderita tekanan darah tinggi.Hasil dari Riset Kesehatan Dasar (RISKESDAS) 2013 secara nasional 25,8\% penduduk Indonesia menderita hipertensi, sementara untuk Aceh jumlah penderita hipertensi mencapai $21,5 \%{ }^{2,3}$.

Pengobatan hipertensi dapat ditempuh dengan menjalani gaya hidup sehat dan konsumsi obat antihipertensi, bisa menjadi langkah efektif untuk mengatasi hipertensi. Nilai tekanan darah dan risiko pasien terserang komplikasi, seperti serangan jantung dan stroke, akan menentukan pengobatan yang akan dijalani. Keberhasilan pengobatan pada pasien hipertensi dipengaruhi oleh beberapa faktor, salah satunya adalah kepatuhan dalam mengkonsumsi obat ${ }^{4}$. Kepatuhan dalam pengobatan (medication compliance) adalah mengkonsumsi obat hipertensi yang diresepkan dokter dan dosis yang tepat dalam pengobatan hanya akan efektif apabila mematuhi ketentuan dalam meminum obat. Beberapa faktor yang mempengaruhi kepatuhan antara lain adalah: pengetahuan, motivasi, dan dukungan keluarga. ${ }^{5}$

Pengetahuan merupakan kemampuan seseorang untuk memutuskan tindakan apa yang akan dilakukan ${ }^{6}$. Pengetahuan penderita hipertensi sangat berpengaruh pada sikap untuk patuh berobat. Semakin tinggi pengetahuan maka keinginan untuk patuh berobat juga semakin meningkat sehingga penyakit komplikasi yang akan ditimbulkan akan menurun. Saputro (2009) menyatakan bahwa terdapat hubungan yang bermakna antara tingkat pengetahuan pasien dengan kepatuhan minum obat ${ }^{8}$.

Motivasi merupakan suatu dorongan kehendak yang menyebabkan seseorang akan melakukan suatu perbuatan untuk mencapai tujuan tertentu. Motivasi berasal dari kata motif yang berarti "dorongan" atau rangsangan atau "daya penggerak" yang ada dalam diri seseorang. Oleh karena itu, motivasi paling kuat ada dalam diri individu sendiri. Motivasi individu ingin tetap mempertahankan kesehatannya sangat berpengaruh tehadap faktor-faktor yang berhubungan dengan perilaku penderita dalam kontrol penyakitnya ${ }^{9}$.

Dukungan keluarga adalah sikap, tindakan dan penerimaan keluarga terhadap anggotanya. Anggota keluarga yang bersifat mendukung selalu siap memberikan pertolongan dan bantuan jika diperlukan. Dukungan keluarga dapat menjadi faktor yang berpengaruh dalam menentukan keyakinan dan nilai kesehatan individu serta menentukan program pengobatan yang diterima ${ }^{10}$. Data dari Puskesmas Peukan Bada Kabupaten Aceh Besar menunjukan bahwa 50\% pasien penderita hipertensi tidak patuh minum obat

Berdasarkan latar belakang yang telah diuraikan sebelumnya, maka penulis berkeinginan untuk melakukan penelitian mengenai faktor pengetahuan, motivasi dan dukungan keluarga yang berhubungan dengan kepatuhan minum obat anti hipertensi di Puskesmas Peukan Bada Kabupaten Aceh Besar.

\section{METODE PENELITIAN}

Penelitian ini merupakan penelitian kuantitatif yang menggunakan desain deskriptif analitik dengan pendekatan cross sectional. Populasi pada penelitian ini adalah seluruh penderita hipertensi di wilayah kerja Puskesmas Peukan Bada, pada kategori hipertensi tahap 1 dan hipertensi tahap 2, sebanyak 126 orang. Berdasarkan perhitungan dengan menggunakan rumus Slovin maka jumlah sampel yang akan diambil sebanyaak 56 orang penderita hipertensi yang berusia 26-> 65 tahun dengan tingkat pendidikan dari Sekolah Dasar sampai Perguruan Tinggi. 
JKT, 2019;10(1):30-35. Hubungan antara Pengetahuan, Motivasi, dan Dukungan.

Sari Hanum, Nona Rahmaida Puetri, Marlinda, Yasir

Pengumpulan data dilakukan di Puskesmas Peukan Bada Aceh Besar pada bulan Mei 2016 dengan menggunakan metode simple random sampling. Analisis data menggunakan chi-square test. Variabel pada penelitian ini adalah tingkat pengetahuan, motivasi dan dukungan keluarga pasien hipertensi. Data diperoleh melalui wawancara menggunakan kuesioner. Tingkat pengetahuan dengan ketentuan skor benar dan salah, dengan rentang baik, apabila $x>6,73$, dan tidak baik apabila $x<6,73$, sedangkan motivasi dengan penilaian Ya dan Tidak dengan ketentuan Tinggi apabila x. $>3,50$ dan Rendah apabila $\mathrm{x}<3,50$. Untuk penilaian dukungan keluarga Ya dan Tidak dengan kategori baik apabila $\mathrm{x}>8,25$ dan kategori tidak baik apabila $\mathrm{x}<8,25$.

\section{HASIL}

Berdasarkan hasil penelitain didapatkan bahwa jumlah penderita hipertensi lebih banyak pada perempuan sebanyak 33 responden $(58,9 \%)$, paling banyak ditemukan pada range usia 46- 55 tahun yaitu sebanyak 21 responden (37,5\%), sebagian besar responden berada pada tingkatpendidikan menengah (SMP-SMA) yaitu sebanyak 27 responden $(48,2 \%)$, dan sebagian besar pada kelompok IRT yaitu sebanyak 25 responden $(44,6 \%)$.

Hasil penelitian pada Tabel 1 menunjukkan bahwa tingkat pengetahuan pasien hipertensi tentang penyakit hipertensi berada pada kategori baik. Hal ini disebabkan oleh banyaknya pemberian informasi mengenai penyakit hipertensi. Pada saat peneliti memberikan pertanyaan kuesioner pasien terlihat tidak bingung untuk menjawab pertanyaan kuesioner wawancara singkat. Tingkat pendidikan berpengaruh pada pengetahuan, tingkat pendidikan responden yang rata-rata menengah memberikan konstribusi pengetahuan yang baik pada responden ${ }^{4}$. Jenis pekerjaan yang paling banyak menderita hipertensi adalah IRT (ibu rumah tangga).

Penelitian ini menunjukkan bahwa sebanyak 31 responden $(55,4 \%)$ memiliki pengetahuan baik dan pengetahuan tidak baik sebesar 44,6\% (25 responden). Hal ini didasarkan pada kuesioner yang terjawab saat wawancara. Sebanyak 10 pertanyaan yang meliputi pengertian hipertensi, faktor usia yang beresiko mengidap hipertensi, konsultasi medis, check up, konsumsi obat/jenis obat yang dikonsumsi. Distribusi frekuensi motivasi responden menunjukkan bahwa sebagian besar memiliki motivasi tinggi yaitu sebanyak 36 responden $(64,3 \%)$ dan memiliki motivasi rendah sebanyak 20 responden $(35,7 \%)$. Distribusi dukungan keluarga terhadap penderita hipertensi menunjukkan sebagian besar baik yaitu sebanyak 34 responden $(60,7 \%)$ dan tidak baik sebanyak 22 responden $(39,3 \%)$.

\section{Hubungan antar Variabel Pengetahuan, Motivasi, dan Tingkat Kepeatuhan Minum Obat Anti Hipertensi}

Tabel 1. Hubungan Pengetahuan dengan tingkat kepatuhan minum obat di Puskesmas Peukan Bada

\begin{tabular}{llllllll}
\hline \multirow{3}{*}{ Pengetahuan } & \multicolumn{6}{l}{ Tingkat Kepatuhan Minum Obat } & \multirow{2}{*}{ Total } \\
\cline { 2 - 7 } & Patuh & \multicolumn{5}{c}{ Tidak Patuh } & \\
\cline { 2 - 7 } Tidak baik & $\mathrm{f}$ & $\%$ & $\mathrm{f}$ & $\%$ & $\mathrm{f}$ & $\%$ \\
\cline { 2 - 7 } Baik & 6 & 24 & 19 & 76 & 25 & 100 \\
\hline
\end{tabular}

Hasil penelitian menunjukkan bahwa dari 31 responden memiliki pengetahuan baik dengan tingkat kepatuhan minum obat patuh sebanyak 22 responden (71\%) dan tingkat kepatuhan minum obat rendah sebanyak 9 responden (29\%). Hasil uji statistik Chi-Square dengan countinuity correction juga menunjukkan bahwa ada hubungan pengetahuan 
JKT, 2019;10(1):30-35. Hubungan antara Pengetahuan, Motivasi, dan Dukungan.

Sari Hanum, Nona Rahmaida Puetri, Marlinda, Yasir

dengan tingkat kepatuhan minum obat anti hipertensi yaitu $(p<0,05)$, hal ini mennunjukan bahwa pada penelitian ini semakin tinggi tingkat pengetahuan maka semakin tinggi tingkat kepatuhan minum obat anti hipertensi pada penderita hipertensi.

Hasil penelitian ini sejalan denganpenelitian sebelumnya yang dilakukan oleh Sarampang, dkk (2014) ${ }^{15}$ tentang "Hubungan Pengetahuan Pasien Hipertensi Tentang Obat Golongan Ace Inhibitor Dengan Kepatuhan Pasien Dalam Pelaksanaan Terapi Hipertensi Di RSUP" didapatkan hasil ada hubungan antara pengetahuan dengan kepatuhan pasien dalam pelaksanaan terapi hipertensi.

Tabel 2. Hubungan Motivasi dengan tingkat kepatuhan minum obat di Puskesmas Peukan Bada

\begin{tabular}{|c|c|c|c|c|c|c|c|}
\hline \multirow{3}{*}{ Motivasi } & \multicolumn{4}{|c|}{ Tingkat Kepatuhan Minum Obat } & \multirow{2}{*}{\multicolumn{2}{|c|}{ Total }} & \multirow{3}{*}{$P$} \\
\hline & \multicolumn{2}{|c|}{ Patuh } & \multicolumn{2}{|c|}{ Tidak Patuh } & & & \\
\hline & $\mathrm{f}$ & $\%$ & $\mathrm{f}$ & $\%$ & $\mathrm{f}$ & $\%$ & \\
\hline Rendah & 4 & 20 & 16 & 80 & 20 & 100 & \\
\hline Baik & 24 & 66,7 & 12 & 33,3 & 36 & 100 & 0,002 \\
\hline
\end{tabular}

Berdasarkan Tabel 2, hasil penelitian menunjukkan bahwa sebanyak 24 responden $(66,7 \%)$ yang memiliki motivasi tinggi dan patuh minum obat, sementara sebanyak 12 responden $(33,3 \%)$ memiliki motivasi rendah dan tingkat kepatuhan minum obat rendah.

Tabel 3. Hubungan dukungan keluarga dengan tingkat kepatuhan minum obat di Puskesmas Peukan Bada

\begin{tabular}{llllllll}
\hline \multirow{2}{*}{$\begin{array}{l}\text { Dukungan } \\
\text { Keluarga }\end{array}$} & \multicolumn{6}{l}{ Tingkat Kepatuhan Minum Obat } & \multirow{4}{*}{ Total } \\
\cline { 2 - 7 } & Patuh & \multicolumn{5}{c}{ Tidak Patuh } & \\
\cline { 2 - 6 } Tidak Baik & $\mathrm{f}$ & $\%$ & $\mathrm{f}$ & $\%$ & $\mathrm{f}$ & $\%$ \\
\hline & 10 & 45,5 & 12 & 54,5 & 22 & 100 & \\
\hline baik & 18 & 52,9 & 16 & 47,1 & 34 & 100 & \\
\hline
\end{tabular}

Berdasarkan tabel 3, hasil penelitian menunjukkan bahwa 18 responden $(52,9 \%)$ yang mendapatkan dukungan keluarga baik dan tingkat kepatuhan minum obat patuh sebesar.sedangkan responden yang dukungan keluarga tidak baik dan tingkat kepatuhan minum obat tidak baik sebanyak 12 responden (54,5\%). Hasil uji statistik Chi-Square dengan countinuity correction menunjukkan bahwa tidak ada hubungan dukungan keluarga dengan tingkat kepatuhan minum obat anti hipertensi $(p>0,05)$. Artinya pada penelitian ini dukungan keluarga tidak berhubungan dengan kepatuhan minum obat anti hipertensi.

\section{BAHASAN}

Responden perempuan lebih banyak menderita hipertensi dibandingkan dengan responden laki-laki, hal ini dikarenakan faktor hormonal (penurunan hormon estrogen)pada wanita ${ }^{11,12}$. Pertambahan usia juga berpengaruh dalam jumlah penderita hipertensi, terutama ketika memasuki usia lebih dari 45 tahun, hal ini sesuai dengan pernyataan Smeltzer \& Bare 2011 bahwa semakin bertambah usia perubahan struktur dan fungsi pada sistem pembuluh perifer bertanggung jawab terhadap perubahan tekanan 
JKT, 2019;10(1):30-35. Hubungan antara Pengetahuan, Motivasi, dan Dukungan.

Sari Hanum, Nona Rahmaida Puetri, Marlinda, Yasir

darah $^{12}$. Tingkat pendidikan berpengaruh pada pengetahuan, tingkat pendidikan respondenmemberikan konstribusi pengetahuan terhadap penyakit hipertensi ${ }^{4}$. Ibu rumah tangga paling banyak menderita hipertensi hal ini sejalan dengan penelitian yang dilakukan oleh Mumtahinnah (2008) bahwa pekerjaan ibu rumah tangga yang monoton dapat memicu stres ${ }^{13}$, dimana Stres dapat memicu tekanan darah tinggi /hipertensi ${ }^{14}$.

Penelitian ini menujukkan bahwa sebanyak 31 responden $(55,4 \%)$ berpengetahuan baik hal ini didasarkan pada sebagian besar responden memahami tentang hipertensi, faktor usia yang beresiko mengidap hipertensi, konsultasi medis, check up, konsumsi obat/ jenis obat yang dikonsumsi dan Perilaku Hidup Bersih dan Sehat yang dijalankan. tingkat Pengetahuan responden tentang hipertensi baik, check up rutin dan mengatur pola hidup menjadi lebih sehat, namun responden masih lalai dalam menjalankannya, hal ini disebabkan oleh kebiasaan hidup yang belum berperilaku sehat dan dipengaruhi lingkungan tempat tinggal responden. Responden yang tidak memiliki pengetahuan baik mengenai hipertensi maka disarankan kepada pihak Puskesmas Peukan Bada untuk lebih rutin memberikan penyuluhan tentang penyakit hipertensi kepada pasien, hal ini sesuai dengan teori Notoatmodjo $(2007)^{6}$ yang menyatakan bahwa pengetahuan yang dimiliki seseorang merupakan dasar untuk berbuat, karena itu kemampuan seseorang melakukan sesuatu tergantung pengetahuan yang dimiliki orang tersebut.

Motivasi penderita hipertensi di Wilayah Kerja Puskesmas Peukan Bada dilihat secara statistic sebagian besar tinggi yaitu sebanyak 36 responden (64.3\%). Ini bermakna berdasarkan hasil uji statistik diketahui $p=0,002<0,05$ sehingga dapat disimpulkan adanya hubungan motivasi dengan tingkat kepatuhan minum obat anti hipertensi , hal ini dapat disebabkan karena adanya kebutuhan dari responden untuk sembuh dari sakitnya. Dengan adanya motivasi yang tinggi dari pasien hipertensi berarti ada suatu keinginan dari dalam diri responden untuk menjalani pengobatan secara teratur.

Dukungan keluarga sangat diperlukan oleh penderita hipertensi, karena seseorang yang sedang sakit membutuhkan perhatian dari keluarga. Dukungan keluarga adalah sikap, tindakan dan penerimaan keluarga terhadap penderita yang sakit. Keluarga juga berfungsi sebagai sistem pendukung, selalu siap memberikan pertolongan dengan bantuan jika diperlukan. Salah satu upaya untuk menciptakan sikap penderita patuh dalam pengobatan adalah dengan adanya dukungan keluarga. Hal ini karena keluarga sebagai individu terdekat dari penderita. Tidak hanya memberikan dukungan dalam bentuk lisan, namun keluarga juga harus mampu memberikan dukungan dalam bentuk sikap. Misalnya, keluarga membantu penderita untuk mencapai suatu pelayanan kesehatan. Dukungan keluarga memepengaruhi kepatuhan pasien hipertensi. ${ }^{16}$ Hasil penelitian ini tidak sejalan dengan hasil penelitian Fitra yang menyatakan bahwa hubungan antara dukungan keluarga dengan pengetahuan sangat kuat ${ }^{17}$.

\section{SIMPULAN}

Berdasarkan hasil penelitian dapat disimpulkan bahwa faktor yang berhubungan dengan tingkat kepatuhan minum obat pasien hipertensi adalah : pengetahuan dan motivasi, sedangkan faktor dukungan keluarga pasien tidak berhubungan

\section{SARAN}

Puskesmas dan keluarga diharapkan lebih menggiatkan kegiatan penyuluhan tentang hipertensi kepada pasien, agar pasien mau berobat dengan serius untuk mengurangi resiko penyakit lain yang disebabkan oleh hipertensi terus menjalankan pola hidup sehat dan berolahra secara rutin. 
JKT, 2019;10(1):30-35. Hubungan antara Pengetahuan, Motivasi, dan Dukungan.

Sari Hanum, Nona Rahmaida Puetri, Marlinda, Yasir

\section{UCAPAN TERIMA KASIH}

Ucapan terima kasih kami ucapkan kepada Pimpinan Fakultas Kesehatan Masyarakat Universitas Muhammadiyah, Kepala Loka Litbang Biomedis Aceh dan seluruh tim yang mendukung terlaksananya penelitian dan penulisan ini.

\section{RUJUKAN}

1. Darmojo R. Buku Ajar Boedhi-Darmojo: Geriatri (Ilmu Kesehatan Usia Lanjut) (Edisi 4) Balai Penerbit FKUI. Jakarta; 2011.

2. Widyani R. Penderita Hipertensi Terus Meningkat. http://lifestyle.kompas.com/read/2013/04/05/1404008/Penderita.Hipertensi.Terus.Mening kat. Published 2013.

3. Kementerian Kesehatan. Profil Kesehatan Indonesia 2014. Vol 51. Jakarta; 2015. doi:10.1037/0022-3514.51.6.1173.

4. Morisky, D. \& Munter P. New Medication Adherence Scale Versus Pharmacy Fill Rates in Seniors With Hypertension. 2009;15(1):59-66. http://www.ajmc.com/journals/issue/2009/2009-01-vol15-n1/jan09-3892p59-66/.

5. Maharani EP. Faktor-faktor Risiko Osteoartritis Lutut. Tesis. 2007. http://eprints.undip.ac.id/17308/1/Eka_Pratiwi_Maharani.pdf.

6. Notoadmojo S. Promosi Kesehatan Dan Perilaku Kesehatan. Jakarta; 2012. belbuk.com.

7. Gama, K. I. Faktor penyebab ketidakpatuhan kontrol penderita hipertensi. Jur Keperawatan Politek Kesehat Denpasar. 2009.

8. Saputro, H T. Hubungan Tingkat Pengetahuan Pasien Tentang Hipertensi dengan Sikap Kepatuhan dalam Menjalankan DIIT Hipertensi di Wilayah Puskesmas Andong Kabupaten Boyolali. Fak ilmu Kesehat Univ muhammadiyah surakarta 2012. 2009. http://eprints.ums.ac.id/6409/1/J210050024.pdf.

9. Niven N. Psikologi Kesehatan : Pengantar Untuk Perawat \& Profesional Kesehatan Lain / Neil Niven; Alih Bahasa Agung Walu. Jakarta: SGC; 2012.

10. FRIEDMAN MM, BOWDEN VR, JONES EG. Buku Ajar Keperawatan Keluarga: Riset, Teori Dan Praktik. Jakarta: http://ucs.sulsellib.net//index.php?p=show_detail\&id=25907.

11. Nainggolan D, Armiyati Y, M S. Hubungan Dukungan Keluarga Dengan kepatuhan Diit Rendah Garam dan Keteraturan Kontrol Tekanan Darah Pada Penderita Hipertensi Di Poliklinik RSUD Tugurejo Semarang. J Chem Inf Model. 2013;53(9):1689-1699. doi:10.1017/CBO9781107415324.004.

12. Smeltzer SC. Buku Ajar Keperawatan Medikal Bedah Edisi 8 Vol.2. Jakarta; 2001. http://akper-adihusada.ac.id/perpustakaan/detailbooks.php?idbook=3647\&judul=Buku ajar Keperawatan Medikal Bedah ( Brunner \& Suddarth ) Edisi 8 vol.2\&koleksi=active.

13. Mumtahinnah N. Hubungan antara stres dengan agresi pada ibu rumah tangga yang tidak bekerja. Fak Psikol Univ Gunadarma. 2008;1(1):1-16. http://www.gunadarma.ac.id/library/articles/graduate/psychology/2008/Artikel_1050217 3.pdf.

14. Islami KI. Hubungan antara stres dengan hipertensi pada pasien rawat jalan di Puskesmas Rapak Mahang Kabupaten Kutai Kartanegara Provinsi Kalimantan Timur. 2015. http://eprints.ums.ac.id/39382/1/02. Naskah Publikasi.pdf.

15. Annisa AFN, Ansar J, wahiduddin. PADA LANSIA DI PUSKESMAS PATTINGALLOANG KOTA MAKASSAR Factors Associated With Hypertension On Compliance For The Elderly In Pattingalloang Health Center The City Of Makassar Bagian Epidemiologi Fakultas Kesehatan Masyarakat Universitas Hasanuddin PENDAHULuan. 2013;1:1-11.

16. Friedman MM. Buku Ajar Keperawatan Keluarga: Riset Teori \& Praktik Ed.5. EGC. 2010. http://dutailmu.co.id/product45634-buku-ajar-keperawatan-keluarga-riset-teori--praktiked5.html\#.WdxTOVtL9pg.

17. Yeni Fitra, Dukungan Keluarga Memengaruhi Kepatuhan Pasien Hipertensi, Jurnal Keperawatan Indonesia,vol 19 No 3, November 2016. 